\title{
The Timelessness of Art as Epitomized in Shelley's Ozymandias
}

\author{
Krishna Daiya \\ Government Engineering College, Rajkot \\ E-mail: nirmohhikrishna@gmail.com
}

Doi:10.7575/aiac.alls.v.5n.1p.154

URL: http://dx.doi.org/10.7575/aiac.alls.v.5n.1p.154
Received: 05/01/2014

Accepted: 27/02/2014

\begin{abstract}
Percy Bysshe Shelley was a poet whose name itself is a Metaphor for exquisite, rhythmic poetry laden with images of Nature as well as Man. He possesses the magical power of transporting the reader into an alternative world with the unique use of metaphors and imagery. His personal sadness was translated into sweet songs that are echoed in the entire world defying all boundaries and straddles. One of the most renowned works of Shelley, Ozymandias is a sonnet that challenges the claims of the emperors and their empires that they are going to inspire generations to come. It glorifies the timelessness of art. The all-powerful Time ruins everything with its impersonal, indiscriminate and destructive power. Civilisations and empires are wiped out from the surface of the earth and forgotten but there is something that outlasts these things and that is art. Eternity can be achieved by the poet's words, not by the ruler's will to dominate.
\end{abstract}

Keywords: Art, Civilizations, Empires, Eternity, Time

\section{Introduction}

The period from the last decade of the eighteenth century to the opening decades of the nineteenth century is an era of revolutionary social changes in all fields, economic, political, religious and literary. In England, the older economy of agriculture and domestic handicrafts gradually gave way to industry. Parallel to that, between 1776 and 1832 , the writings of the French intellectuals began to be freely circulated in England. There was also the American example in setting up a constitution without hereditary legislators. The French Revolution (1789-99) and War with France (1793) changed the very fabric of the European society, including the English Society.

\section{Influence of Social Changes on Literature}

The ideals of the French Revolution had kindled the flame of hope in writers like Wordsworth and Coleridge. They were thrilled with the ideals of Liberty, Equality and Fraternity and hailed the new era with a lot of joy and enthusiasm. This was reflected in their poetry. But each revolution and each movement has its own ebb and flow. It has a wave-like structure with the Rise, Climax and Fall. The failure of the French Revolution led to disappointment and dejection. The ardour and eagerness of the poets and their poetry faded into despair and disillusionment. The younger writers like Leigh Hunt, Shelley and Keats still adhered to the doctrines of the French Revolution, but the warmth of the earlier days had disappeared.

\section{Literary Conditions of the Time}

In the Literature of this era, we come across a consistent strain, and that is Return to Nature. The literary output was abundant and excels even that of the Elizabethan Literature. There were new ideas and fresh inspiration. The prose of this Age heralds the rejuvenation of the Essay. Many novels and a lot of critical and miscellaneous works were written. The poetry is marked with Romanticism, Nature and Imagination.

\section{Percy Bysshe Shelley}

A free spirit, a loving human being and an exceptional poet with an extraordinary imagination, Percy Bysshe Shelley breathed fresh ideas and spectacular descriptions in his lyrical dramas, long poems and short poems. He also wrote critical works. Though born with a silver spoon in his mouth, his life was full of misfortunes arising out of the displeasure of parents, University and society. He was expelled by University due to his pamphlet entitled "The Necessity of Atheism". He was called "Mad Shelley". However, his poetry derived beauty out of his sad thoughts:

Teach me half the gladness

That thy brain must know.

Such harmonious madness

From my lips would flow, 
The world should listen then-

As I am listening now. (Shelley’s To a Skylark)

\section{Ozymandias}

One of the most well-known and oft-anthologised works of Shelley, Ozymandias is a sonnet that defies the claims of the emperors and their empires that they are going to inspire generations to come and glorifies the timelessness of art. It was first published in January $11^{\text {th }}$, 1818 Issue of The Examiner in London under the penname Glirastes. It was later incorporated in Shelley's collection Rosalind and Helen, A Modern Eclogue; with Other Poems in 1826. After his death, it was included in a posthumous compilation of his poems published in 1826.

\section{Inspiration}

The sonnet was inspired by the announcement of the British Museum's acquisition of a large fragment of a statue of Ramesses II from the thirteenth century BC. Ozymandias is an alternative name for the Egyptian pharaoh Ramesses II. In 1816, the Italian adventurer Giovanni Battista Belzoni recovered the 7.25 ton fragment of the statue's head and torso from the mortuary temple of Ramesses at Thebes.

It is believed by scholars that the description of the statue motivated Shelley to write a poem on it. Hence, the inspiration is more verbal, rather than visual. Shelley wrote the poem in friendly competition with his friend and fellow poet Horace Smith, who also write a sonnet on the topic. Horace's sonnet was also published in The Examiner a few weeks after Shelleys'.

The sonnet also seems to have its roots in the text by the Roman-era historian Didorus Siculus, who described the statue of Ozymandias. Didorus reports the inscription on the statue:

King of Kings Ozymandias am I. If any want to know how

great I am and where I lie, let him outdo me in my work.

\section{Title of the Poem}

'Ozymandias' is the name for the Egyptian pharaoh Ramesses II. It also represents a transliteration into Greek of a part of Ramesses' throne name User-maat-re Setep-en-re. The word 'Ozymandias' also appears in the inscription on the base of the statue, given by Didorus Siculus.

Shelley chose the name 'Ozymandias' in place of 'Ramesses II' probably because it is associated with the Greek civilization. This leads to the sharing of cultures between the two greatest civilizations of the western world, Greek and Egyptian. Aaron Biterman says,

Ozy comes from the Greek 'ozium' which means to breathe, or air. Mandias comes from the Greek 'mandate', which means to rule. (Biterman 2000).

Connecting this to Shelley's poem, Biterman adds,

Hence, Ozymandias is simply a 'ruler of air', or a 'ruler of nothing'. It is then obvious that the king of kings spoken of in the poem is actually Nature itself. (Biterman 2000)

\section{The Timelessness of Art}

The masterful sonnet has an elusive, sidelong approach to its subject. The poem begins with the word 'I' that hastens to fade away in favour of a traveller who comes from an antique land. The wayfarer then takes up the narration. "The two vast and trunkless legs of stone" without the torso in the strange, desolate landscape described by the explorer introduce us to the ruins of a vast empire. The visage is half-sunk in sand and shattered, describing the time's ruinous force.

Shelley then brings up the facial expression. There is the "Frown, / And wrinkled lip, and sneer of cold command." The "cold command" is the symbol of the tyrannical empire building ruler.

The focus now shifts from the explorer to the sculptor. He becomes the mediating figure as he communicates the tyrant's passions hidden beneath the cold exterior. The ruler has this insatiable urge to conquer the world and bring it under his control and power. The sculptor "well those passions read" and these intense emotions are reflected in his work, the statue. The artist's mockery lies in his depiction of Ozymandias in the statue. "The heart that fed" refers to the sculptor's own fervent way of nourishing himself on his project.

The sestet shifts our attention from the shattered statue to its pedestal with the inscription:

My name is Ozymandias, King of kings. Look on my

works ye Mighty, and despair. (Ozymandias)

The irony of the situation is that around the statue no works are visible. It is just a vast desert wasteland. The kings that Ozymandias challenges must be the rival rulers of the countries that he has enslaved. The pedestal stands in the middle 
of an infinite empty space, described by two phrases: "boundless and bare", and "lone and level". The pharaoh's political will that led him to conquer lands has bore no fruit. His life work is as barren and empty as the vast expanse.

The once great king's proud boast has been reduced to dust. His works have crumbled and disappeared. The allpowerful Time ruins everything with its impersonal, indiscriminate and destructive power. Thus, the statue becomes an epitome of the ephemeral political power and of pride and hubris of all humanity.

However, a glaring contrast to these ruins of a great empire is provided by a work of art and a group of words. Civilisations and empires are wiped out from the surface of the earth and forgotten but there is something that outlasts these things and that is art. Eternity can be achieved by the poet's words, not by the ruler's will to dominate.

\section{Form}

'Ozymandias' is a sonnet, a fourteen line poem written in Iambic Pentameter. It is not strictly a Petrarchan sonnet. However, it interlinks the Octave (the first eight lines) with the Sestet (the last six lines) by gradually replacing the old rhymes with the new ones. The Rhyme Scheme is ABABACDC EDEFEF.

\section{Imagery \& Metaphors}

The entire poem is devoted to a single metaphor: the shattered, ruined statue in the desert wasteland, with its arrogant, passionate face and inscription. It becomes a metaphor for the fallen and destroyed dream of the powerful, cruel ruler and the ironic and hollow words etched onto the statue's base.

Shelley's use of imagery reconstructs the figure of the "King of kings". At first, the two legs are described, then the "shattered visage", and then the face itself with it's "frown / And wrinkled lip and sneer of cold command." The sculptor then comes alive in front of our mind's eye. We are able to imagine the living man sculpting a live king, whose face bore the expression of patience. The image of the desert, boundless and bare, with the lone and level sands stretching far away, demolishes the picture of the mighty king who boasted of his works.

\section{Narration}

Shelley uses the technique of Distanced Narration. The sonnet is framed as a story told to the speaker by a traveller. This adds obscurity to the position of Ozymandias. Neither the reader nor the narrator has seen the statue. Even the narrator hears it from someone else who has seen it. Thus, the ancient king is rendered even less commanding. It absolutely undermines his power.

\section{Conclusion}

Shelley's poetic rendering of the legend of Ozymandias is even more memorable than the original story itself. It is also an emphatic political statement indicating the cruel and destructive nature of the empires of man and their outcomes. This beautiful sonnet outlasts the so-called mighty empires based on control and terror. These empires get eroded and destroyed leading to disintegration of civilization and culture. However, neither time nor distance can obliterate the works of art making the artist immortal.

\section{References}

Biterman, A. (2000). Analysis of Ozymandias." Personal web page. Analysis of Ozymandias. Dec. 2000. Web. 12 Mar. 2012. http://chelm.freeyellow.com/ozymandias1.html.

Glirastes (Percy Bysshe Shelley), (1818). Original Poetry. Ozymandias". The Examiner, A Sunday Paper, on politics, domestic economy and theatricals for the year 1818 (p. 24). London: John Hunt.

Shelley, P. B. (1826). Ozymandias" in Miscellaneous and Posthumous Poems of Percy Bysshe Shelley (p.100). London: W. Benbow.

Shelley, P. B. (1876). Ozymandias". Reprinted in Rosalind and Helen - Edited, with notes by H. Buxton Forman, and printed for private distribution (p. 72). London: Hollinger.

Shelley, P. B. (1820). To a Skylark. http://www.poetryfoundation.org/poem/174413. 